\title{
„[...] sprowadzić na świat nowe dzieci, za tamte, spalone" \\ Z Irit Amiel o życiu i pisaniu rozmawia Marta Tomczok
}

Marta Tomczok: Czy zanim zaczęła Pani regularnie publikować, pisała Pani dla siebie? Czego dotyczyły te zapiski?

Irit Amiel: Od czasu, kiedy nauczyłam się sama czytać i pisać w wieku lat pięciu w Częstochowie, wiedziałam, że chcę zostać pisarką. Zawsze interesowali mnie ludzie i ich rozmowy, zapamiętywałam często zdania, które dorośli mówili w mojej obecności. Nie chodziłam do szkoły, bo rodzice chcieli zaoszczędzić mi licznych, codziennych oznak otwartego antysemityzmu w mieście, jakim była Częstochowa, i w związku z tym poczucia poniżenia. Lubiłam pisać krótkie wierszyki oraz opowiadanka, na początku dla siebie. Pamiętam, że zawsze to było smutne. A potem, jak wszystkim wiadomo, wybuchła wojna, która trwała sześć lat, a ja miałam osiem lat i żyłam dwa lata w częstochowskim getcie, potem tułałam się po wsiach i w Warszawie na aryjskich papierach. Po wojnie, kiedy zrozumiałam, że moi rodzice już nie wrócą i że w Polsce nadal nie polubiono Żydów, postanowiłam opuścić kraj. Dołączyłam do istniejącej międzynarodowej organizacji syjonistycznej, śladami bohatera powstania w getcie warszawskim Antka Cukiermana, którą otworzył przed nami w Częstochowie. Była wtedy taka sytuacja w Polsce, że ocaleni Żydzi byli w panice, że nie będzie już europejskich Żydów, bo wybito dzieci! Żydzi zawsze szybko tworzą organizacje pomocy, żeby mieć się do kogo zwrócić, dlatego prędko wynajmowano furmanki, które jeździły po wsiach, klasztorach, szukając ukrywanych żydowskich dzieci i młodzieży. Pojęto, że naród żydowski w Europie zginął na zawsze razem z tymi dziećmi. Były one szczególnie ważne, bo ta wojna była właściwie przeciwko dzieciom, przeciwko przyszłości narodu żydowskiego. Doszliśmy do wniosku, że Żydzi muszą mieć swój kraj, bo państwa europejskie nas nie znoszą. Antek Cukierman, który objeżdżał Polskę w poszukiwaniu ocalonych, zaproponował nam zbudowanie w Palestynie nowej ojczyzny dla Żydów, według Altneueland 
Theodora Hertzla. Nasza nielegalna droga do Palestyny trwała kolejne dwa i pół roku. Żyliśmy jako uchodźcy w obozach dipisów w Niemczech, w Austrii, to znaczy w byłych obozach koncentracyjnych i wojskowych, skąd przekradaliśmy się pieszo przez granicę austriacko-włoską, żeby zbliżyć się do Morza Śródziemnego, a stamtąd starymi wojennymi i handlowymi okrętami, podarowanymi nam przez naszych braci - amerykańskich Żydów, płynęliśmy do Palestyny.

Pisałam też dziennik po drodze, ale te zapiski zginęły na Cyprze. W Izraelu natomiast obiecałam sobie, że jak długo nie jestem zdolna napisać wiersza czy opowiadania w języku hebrajskim, nie będę pisać nic.

M.T.: Czy literatura Zagłady i o Zagładzie, która zastała Panią w czasie publikowania, ta istniejąca w chwili Pani debiutu w połowie lat 90., miała dla Pani znaczenie? Jak ją Pani czytała, oceniała, przeżywała?

I.A.: Kiedy byliśmy w drodze do Izraela, inni pisali, pisali literaturę Zagłady i o Zagładzie. Cały czas czytałam, aż opanowałam możliwość pisania w moim nowym języku. Trwało to długie lata, podczas których nosiłam to wszystko w sobie, a czytałam wszystko, co było dostępne dla mnie w Izraelu, o tym, co nam się stało. Levi, Améry, Borowski, Wojdowski, Stryjkowski, Wygodzki, Ginczanka, Kosiński, Krall, Rudnicki. Cała dostępna wówczas i później literatura o Zagładzie, aż do lat 90., była główną literaturą, którą czytałam, przeżywałam i oceniałam. Czytałam ją, jak wszyscy, we łzach, a oceniałam, co jest prawdziwe. Czasem myślałam, że część musi być wymyślona. Były też takie książki, które uważałam, że są może wzruszające, ale akurat nie dla mnie. Zawsze interesowało mnie, jak inni oceniają Zagładę i jak inni to z siebie wyrzucają. Oczywiście, że wywarła ogromny wpływ na to, co się pamięta. Ze wszystkich, którzy wtedy do mnie dotarli, oczarowana byłam Henrykiem Grynbergiem, przede wszystkim zaczytywałam się nim i czytałam go sercem i łzami, zwłaszcza jego Ekipę „Antygona” i Żydowską wojnę. Podziwiałam go od pierwszego opowiadania. W obozie dipisów w Niemczech przyniesiono nam skrzynię z książkami, z których tylko dwie były po polsku, a reszta po niemiecku. Przypominał mi on jidysz i tak nauczyłam się niemieckiego. Nareszcie mogłam nasłuchać się, co nam zrobiono i jak. Czytanie po polsku literatury o Zagładzie zastało mnie w czasie, kiedy starałam się zapanować dobrze nad hebrajskim. Tonęłam w tych tekstach i nie miałabym odwagi zadebiutować moimi skromnymi opowiadaniami, gdyby po latach nie zwróciła uwagi na jedno z nich, wydrukowane w „Midraszu”, pani Agata Patalas, nauczycielka nauczycieli w Warszawie, która posłała je do Jerzego Giedroycia do Paryża. Mój debiut nastąpił, kiedy miałam sześćdziesiąt lat. Wtedy wydałam swoje wiersze. Wcześniej wiedziałam, że trzeba koniecznie nie tylko zbudować kraj dla Żydów, ale i zbudować rodzinę, sprowadzić na świat nowe dzieci, za tamte, spalone. Dopiero później przyszło do mnie przekonanie, że jeśli mam tę możliwość, muszę pisać, muszę opowiadać na różne możliwe dla mnie sposoby. 
M.T.: Czy praca tłumacza wpłynęła na Pani podejście do pisania?

I.A.: Oczywiście, że praca tłumacza wpływa na podejście do własnej twórczości, ta też wpłynęła i na mnie. Lubię tłumaczyć to, co mi się podoba. To była tylko próba językowa, żeby się postawić na nogi, to takie raczkowanie, które otwiera możliwość przetłumaczenia czegoś, co napisał ktoś inny. Tłumacząc, używa się swojej mocy przekładania na inny język. Muszę przyznać jednak, że tłumaczyłam głównie z powodów finansowych.

Napisałam wiersze po hebrajsku, ale czułam, że nie są gotowe, nie są kompletne, czegoś im brakuje. Wtedy zrozumiałam, że wszystko musi być w obu językach.

Któregoś dnia wstałam rano, podniosłam poduszkę i znalazłam skarb, na własność! Ten skarb to moja głęboka znajomość języka polskiego, w którym mogę opowiedzieć wszystko o wszystkim, mimo że hebrajski znam bardzo dobrze. Przecież to była jedyna rzecz, którą my, osmaleni, mogliśmy wywieźć ze sobą z Polski, choć była przedwojenna.

M.T.: Tłumaczyła Pani między innymi utwory Leo Lipskiego. Jakie problemy napotkała Pani w pracy z jego prozą? Jak jest ona obecna w Izraelu?

I.A.: Pana Lipskiego poznałam osobiście, było to w czasach, kiedy kręcił się po naszych alejach telawiwskich z ręką na temblaku, a temblak był zawsze kolorowym krawatem. Tak naprawdę Lipskim niestety interesowało się niewiele ważnych osób, głównie krakowian. Tłumaczyłam Lipskiego, myślę tutaj o jego opowiadaniu Sarni braciszek, bo było mi ono bardzo bliskie, przemówiło do mnie i tylko to przetłumaczyłam, natomiast inne jego utwory, o obozach i jego romansach, były mi dość obce, niezrozumiałe. Wtedy, w latach 90., było tu sporo inteligentnych osób z Polski, które się tym zajmowały. To był szczyt inteligencji polsko-izraelskiej. Jego proza jakoś wślizgnęła się do kultury izraelskiej, mnie się zdaje, że Piotruś bardzo wpłynął na twórczość innego znanego izraelskiego dramaturga, Hanocha Levina. W ten sposób proza Lipskiego jest obecna w Izraelu. Ogólnie jest bardzo znana i szanowana, ale znana tylko polskim sferom.

M.T.: Przetłumaczyła Pani To jest morderstwo Mieczysława R. Frenkla, książkę wydaną przez „Śląsk” w 1958 roku i dziś właściwie nieobecną w Polsce, niewznawianą. Co sprawiło, że zainteresowała się Pani tą prozą?

I.A.: Przetłumaczyłam ją ze względów finansowych. Zaproponował mi to pewien rabin, oficer pochodzący ze Lwowa. Ja bym tego nie wybrała, bo czułam, że to jest opowiadanie o opowiadaniu, bo ten człowiek był w międzyczasie w Rosji. $\mathrm{Na}$ biurku mam wznowioną nowelę na ten temat. Notabene niedawno napisałam nowe opowiadanie oparte na nim. 
M.T.: Wśród powieści czytanych przez Panią w getcie wymienia Pani Anię z Zielonego Wzgórza, Serce Amicisa i Nad czarna woda Haliny Górskiej. Tę ostatnią ze szczególnym sentymentem. Roztacza ona wizję „planety braterstwa”. Górska, lwowska Żydówka, ginie w czasie wojny. Dlaczego ta książka jest dla Pani taka ważna?

I.A.: Trudno odpowiedzieć na to pytanie, bo Pani tak ładnie zapytała, już odpowiadając na nie. Dokładnie właśnie dlatego. W takim świecie ja chciałam żyć, w takim świecie myślałam, że będziemy żyć w Izraelu. Pani sama to tak ładnie określa wizją „planety braterstwa”... Co mnie zainteresowało? Może ta społeczność, która się martwi o innych i innym pomaga... Ja byłam wtedy strasznie naiwna, ale mogłam być, bo miałam wszystko... My wtedy udawaliśmy, że nasza mała społeczność żydowskich dzieci z Częstochowy żyje naprawdę i chodzi do szkoły na niby. Przynosiliśmy skromniutkie śniadanka na nasze komplety i dzieliliśmy je na połowy z dziećmi napływającymi z okolicznych sztetli, które żyły w ogromnej biedzie. Być może był to zalążek mojej miłości do życia kibucowego. Serce Amicisa to też dawanie. Ania z kolei ma przygody, ale nic jej się nigdy nie dzieje, nie wrzucają jej zastrzelonej do dziury.

M.T.: Czy pisząc o getcie w Częstochowie, miała Pani potrzebę porównywania własnych doświadczeń $\mathrm{z}$ doświadczeniami innych autorów opisujących to getto lub inne getta, w których Niemcy zamknęli w czasie wojny Żydów?

I.A.: Tak, interesowały mnie doświadczenia innych gett, mimo że wiedziałam mniej więcej, jak te rzeczy się odbywają. Kiedy pisałam, chciałam, żeby to było zrozumiane, że ja piszę w imieniu wszystkich, bo przecież każdy jeden Niemiec mógł popełnić każdą jedną zbrodnię wedle swoich pomysłów. Pisząc o getcie w Częstochowie, nie miałam potrzeby porównywania własnych doświadczeń, bo znałam to $\mathrm{z}$ autopsji, żyłam przecież $\mathrm{w}$ Warszawie i byłam świadkiem zarówno obu powstań, jak i zamkniętego getta. W Warszawie żyłam z jednym okiem zezującym na getto za murem i z pomocą innych autorów opisujących to getto miałam okazję zobaczyć, jak to wyglądało. Te lata po drodze, kiedy żyłam w obozach, gdzie wszystko było otwarte i żyliśmy wszyscy razem, dały mi szerokość i głębokość przeżycia, uratowania się z tej wojny. Dlatego Zagłada w mojej twórczości przyjmuje postać dziesiątek historii opowiedzianych z perspektywy jej następstw.

M.T.: Czy właśnie tak powinniśmy widzieć Zagładę? Jako główną przyczynę rozpadu najważniejszych ludzkich więzi, katastrofę tysięcy prywatności, ruinę tożsamości, kataklizm rodzin, a zatem nie tylko jako wydarzenie historyczne, ale też jako wydarzenie oddziałujące na życie osobiste ludzi? 
I.A.: Oczywiście! Tak, jak Pani to powiedziała. Zagłada jako wydarzenie historyczne, jak to Pani pięknie określiła, właśnie tym była w istocie dla osmalonych. W mojej twórczości Zagłada przyjmuje postać dziesiątek różnych historii z uwagi na fakt, że blisko trzy lata byłam w wielu obozach dla dipisów: we Włoszech, w Niemczech, na Cyprze. Byłam otoczona wieloma językami i ludźmi oraz ich doświadczeniami, a mam bardzo dobrą pamięć do tego, co ludzie opowiadali. Ja nosiłam te zdania w sobie, czekając, aż przyjdzie dzień, kiedy będę mogła je zapisać.

M.T.: W pamiętniku pisze Pani: „[...] namiętnie pragniesz żyć. Po prostu żyć. Jeść i pić do syta, kochać". Sam pamiętnik zaś nazywa Pani po prostu: Życie tytuł tymczasowy. Jak bardzo istotna jest dla Pani kategoria życia? Czy nie jest ona może ważniejsza od bardziej znanej metafory osmalenia?

I.A.: Kiedy to pisałam, już byłam osmalona. Nie było już Niemców. To wszystko zależy od etapu życia, na którym się znajduję, osmalona byłam na drugi dzień po wojnie, a teraz jestem staruszką, która żyje z ogromną żywotnością. Czy mam się za to usprawiedliwiać? Wszystko zależy od wieku, od tego, jak dużą rodzinę udało mi się powołać do życia. Myślę, że kategoria życia jest bardzo istotna dla ocalonych z Zagłady, ale nie mniej ważna niż bycie osmalonym. Ja szybko zrozumiałam, że trzeba raz-dwa zapełnić stół nowymi ludźmi i jedzeniem, czynem, łzami, książką, piosenką i śpiewem. To był obowiązek każdego osmalonego.

M.T.: W Pani twórczości Zagłada dzieli literaturę na gatunki: wiersze, opowiadania, wspomnienia. Czym różnią się one dla Pani? Które z tych gatunków uważa Pani za najbliższe swojej koncepcji pisania?

I.A.: Nie dzielę moich prac literackich na gatunki, piszę spontanicznie. Czasem wydaje mi się, że dana historia każe być opowiadaniem, a czasem to musi być tylko kilka zdań, wiersz. Jestem tłumaczką, pisarką i poetką. Kocham języki.

M.T.: Michał Głowiński pisał o szczególnej roli opowiadania w opisywaniu doświadczenia Zagłady. W Pani twórczości opowiadania osiągnęły najwyższy poziom. Jest Pani do nich szczególnie przywiązana? Czy są one dla Pani rodzajem dokumentu?

I.A.: Jeśli Pan Głowiński tak mówi, to ja nie będę z nim dyskutowała. Coś musi być $\mathrm{w}$ tych moich opowiadaniach, skoro oba tomiki były nominowane do Nagrody Nike. Dla mnie każdy sposób, łącznie z komiksem, jest dobrym i odpowiednim sposobem utrzymania pamięci, przecież ci ludzie prosili tylko o jedno: pamiętajcie! Nie zapominajcie nas, żeby nie stało się tak, jakby nas nigdy nie było. A czy my to robimy? To jest najważniejsze - pamiętać! Jakimi sposobami 
kto potrafi. Jestem przywiązana zwłaszcza do jednego z moich opowiadań - Pożegnanie mojej martwej klasy. Tu wszystkich ich zabieram ze sobą przecież do Ejlatu. Są ze mną zawsze. Moim zdaniem jest to moje najlepsze opowiadanie, ale może nie mam racji? Myślę, że tak, są to opowiadania, ale oparte na prawdziwych historiach. Napisane dwadzieścia lat temu, kilkanaście lat uczyły się z nich dzieci w szkołach, przetłumaczone na niemiecki, włoski, portugalski, rosyjski, węgierski, angielski, hebrajski, chiński i japoński. Istnieją w dziesięciu językach, dwa razy nominowane do Nagrody Nike. To są prawdziwe historie, o ludziach, którzy już nie żyją, chociaż ja nie potrzebuję dokumentów, ja pamiętam. Mają być pamiętani, tak czy inaczej.

M.T.: Jakie znaczenie nadaje Pani poezji? W Pani twórczości jest ona niekiedy bardzo narracyjna, skupiona na opowiadaniu, a jednocześnie silna i inwazyjna. Takie wrażenie sprawia Film, oddający wyobrażenia podmiotu na temat śmierci w komorze gazowej. Ale można też znaleźć wiersze finezyjnie przetwarzające krążące opowieści o Zagładzie, jak Jedwabne miasteczko.

I.A.: W wierszu dobrze skonstruowanym można opowiedzieć całą książkę dzięki jego skondensowanej formie. Nie używam rymów, bo jestem z Częstochowy, więc mam na rymy alergię. Jak do mojej skrzynki narzędzi wpada miasteczko Jedwabne, to ja nie mogę nie napisać o tym wiersza. Ostatnio długi czas już nic nie napisałam, mój ostatni wiersz jest o śmierci - Ona.

M.T.: Jakie znaczenie przypisuje Pani tradycji żydowskiej, a szczególnie tradycyjnej żydowskiej religijności? W jaki sposób literatura o Zagładzie może się komunikować z tą tradycją?

I.A.: Nasze pokolenie przypomina polskich świeckich Żydów. Lubimy utrzymywać żydowską tradycję, z której jesteśmy dumni, i przekazywać ją kolejnym pokoleniom, ale nie wierzymy, że Pan Bóg stoi i nas pincetką wyciąga z tragedii. Nie było go, był odwrócony. Jestem wielkim niedowiarkiem. Jak wtedy Pan Bóg się nie stawił, to albo się odwrócił, albo go nie ma. Ale bardzo lubię żydowską tradycję. Ja jestem bardzo dumna z tego, że jestem Żydówką. Mądrość moich przodków też sobie zabieram dla siebie, postanowienia życiowe, na przykład wrócić tu, do starożytnego kraju, kiedy powinnam być właściwie polską Żydówką u Pani na Uniwersytecie! Ale polskich Żydów chcieli tylko w najgorszych zawodach, a oni nagle stawali się najlepszymi lekarzami... Tradycja żydowska to wychowanie, niekoniecznie religijne. Zapalić świece chanukowe w oknie tak, jak zapalali moi rodzice w Częstochowie, tak zapalam ja, moje dzieci, moje wnuki i mam nadzieję, że tak będą zapalać moje prawnuki. Co roku w Pesach zorganizować sederową kolację i przeczytać Hagadę, w której jest napisane, że każdy ma widzieć siebie jako człowieka, który wyszedł na wolność z Egiptu, i wiedzieć, że 
w tym samym czasie Żydzi w Brazylii, Ameryce, Polsce i Izraelu mówią te same słowa. To jest tradycja. Te same stare, mądre słowa w tym świętym, starożytnym języku, w którym my żyjemy na co dzień. Tak jak przekazuje się z pokolenia na pokolenie modlitewnik, podaje się tradycję i mądrość $\mathrm{z}$ rąk jednego pokolenia do rąk drugiego. Może też wnioski, jakie się wyciągnęło... Ogromną mądrość odnajduję także w żydowskiej tradycji żałoby. Tak jak siedzi się po zmarłym sziwę, tak my, osmaleni, wstaliśmy w którymś momencie z sziwy i wróciliśmy do życia, by żyć, budować nowy kraj i nowe rodziny.

M.T.: Pani literatura w żaden sposób nie daje się upolitycznić. Znajduje się daleko od dominujących w Polsce sporów o politykę historyczną. Jak je Pani ocenia? Czy są one dla Pani w ogóle ważne? Czy literatura powinna na nie odpowiadać?

I.A.: Wydaje mi się, że Żydów w Polsce jest maleńka grupka, a z pokolenia na pokolenie będzie jeszcze mniejsza, bo Żydzi nie są i nie będą w Polsce chciani. Jeśli chodzi o spory historyczno-polityczne, mogę Pani powiedzieć jedno: kiedy Niemcy weszli do Polski, nie byli w stanie sami odróżnić polskiego świeckiego Żyda od polskiego katolika i gdyby nie pomoc przytłaczającej większości polskiego narodu, czego sama naocznie byłam świadkiem przez lata wojny, zostałaby w Polsce przy życiu o wiele większa społeczność żydowska. Z drugiej strony gdyby nie pomoc Żegoty, choć okrężna i rzadka, nie przeżyłabym tej wojny. Oczywiście, że jestem po stronie Żydów. W ogóle lubię, jak Żydom na świecie jest dobrze. Korzenie antysemityzmu polskiego są bardzo głębokie i osadzone na niezniszczalnym micie o zabiciu Jezusa, który był Żydem i tak ładnie mu się chodziło po Morzu Galilejskim. Jestem daleko, ale myślę, że prochy moich przodków, tych dalekich i tych bliższych, są w tej ziemi. To mnie wiąże. Jestem blisko z polskimi Żydami i Żydówkami. Mogłam być jedną z nich. Zauważyłam, że ludzie lubią biadolić i wchodzić w rolę ofiar. Może tak jest łatwiej, bo można innych obwiniać o swój los. Odkąd rozstałam się z rodzicami, zrozumiałam, że w moich rękach jest odpowiedzialność za mój los i moje czyny. W ogóle jestem dość apolityczna. Mam swoje zapatrywania polityczne, które są raczej lewicowe, ale nie wiem, czy ma to jakiś związek z moim pisaniem. Nie wiem, czy literatura może być dobra, jeśli zacznie zajmować się polityką. Literatura ma być literaturą, powinna być sobą per se, a nie zapatrywaniem politycznym.

M.T.: Otwierające Osmalonych opowiadanie Kartka $z$ pamiętnika dotyczy dnia, w którym po raz ostatni widziała Pani swoich rodziców. Jest to - mimo lakoniczności i pozornej oschłości - wstrząsające opowiadanie. W późniejszej o kilka lat autobiografii Życie - tytuł tymczasowy powtórzyła Pani jego treść, zmieniając jedynie pierwszą osobę liczby pojedynczej na drugą. Czemu miała służyć ta zmiana? 
I.A.: To opowiadanie to mój poród, moja symboliczna historia. Na tym zbudowane jest moje życie. Napisałam je jako pierwsze. Kto czyta książkę, czyta moje sztandarowe opowiadanie: stąd ja jestem. To jest dla mnie najważniejsze z moich opowiadań. A poza tym przez to, że nigdy nie chodziłam do szkoły, byłam samotnym dzieckiem, wykształcił się u mnie taki sposób, może psychologiczny, mówienia do siebie samej. Wygodniej jest mi powiedzieć „ty” lub „ona” niż ,ja”. Jak się mówi „ja”, to jest to bardzo narcystyczne. Byłam jedynaczką, potem jedyną ocalałą, samotną wśród Sabrów, samotną w rodzinie sefardyjskiej mego męża, po polsku mogłam mówić tylko sama ze sobą.

M.T.: Pani pamiętnik to jedyny znany mi przykład świadectwa ocalonej napisany w drugiej osobie liczby pojedynczej. Z czego wynika ten niezwykły wybór?

I.A.: Postanowiłam zrobić to, co robię w codziennym życiu - rozmawiam ze sobą. W tej książce jestem podwójna, bo może podwojona osoba ma szerszą zdolność patrzenia na przeszłość. Może to też kwestia minionych lat? Przez to, że tak młodo zostałam sierotą, w jakiś sposób nastąpił u mnie rodzaj rozdwojenia jaźni. Długo nie byłam tego świadoma, że tak ze sobą rozmawiam. Zdałam sobie w końcu sprawę, że jestem taką babuszką, każdą z nich mogę w każdej chwili przywołać i z nią porozmawiać.

M.T.: O Zagładzie pisze Pani często za pomocą metafor: „potop”, „pożoga”, a o ocalonych „osmaleni”. Czy stoi za tym, trochę magiczny, zamysł, aby unikać zbyt dosłownego języka do opowiadania o własnym doświadczeniu?

I.A.: Chyba tak, między innymi. Potop musiał być, to Natura, ale Zagłady nie musiało być, zrobili ją przecież ludzie. A przecież ja nie opowiadam tylko o sobie, o własnym doświadczeniu, ja opowiadam o doświadczeniu narodu.

M.T.: Jaką rolę odgrywają w Pani publikacjach prace Dity Amiel? Czy tworzą także oddzielną opowieść o relacjach matki i córki?

I.A.: Cieszę się, że zadała Pani to pytanie, nigdy nie zdarzyło mi się mówić o tym, a myślę, że to bardzo ciekawe. Muszę to wytłumaczyć. Ja nie opowiadałam dużo moim dzieciom o Szoa, ale mówiłam codziennie i ze szczyptą ironii oraz humoru. Na wesoło wręcz.

Dita od lat jest projektantką mody i malarką, była fotografką. Nagle kiedyś, patrząc na jej obrazy wiszące u mnie w salonie, zaczęłam zastanawiać się, skąd ona to wzięła. Urodziła się w Izraelu, gdzie od zawsze słońce, jego światło i pomarańczowe zachody, zachwycało europejskich malarzy kolorami (osiem miesięcy trwa u nas lato, a cztery lekka jesienio-zima, nigdy nie trzeba nosić kożucha). A tutaj Dita z tymi ponurymi obrazami, kościołami w alejach, postaciami Cohe- 
nowskimi, szarościami i złoto-żółtymi liśćmi europejskimi. Zastanowiło mnie, czy jest taka możliwość, że podświadomie moje zagładowe przeżycia przeszły na nią, w jej świadomość i zdolności, przecież rosła w moim brzuchu, ja ją urodziłam i wykarmiłam.

W końcu postanowiłyśmy, że wszystkie moje książki będą miały jej okładki. Właśnie w tej chwili szykuje się tomik wierszy przetłumaczonych na portugalski w Brazylii w wydawnictwie „Dybuk”, który też będzie miał obraz Dity na okładce: mężczyzna na moście spoglądający na płynącą rzekę. Chyba to mówi coś o naszych relacjach.

Irit AMIEL - urodzona jako Irena Librowicz 5 maja 1931 roku w Częstochowie. W czasie wojny do 1942 roku przebywała w tamtejszym getcie, następnie ukrywała się m.in. pod Częstochową i w Warszawie. W 1947 roku wyemigrowała do Palestyny - najpierw żyła w kibucach, później zamieszkała w Tel Avivie.

Debiutowała w 1994 roku tomem wierszy Egzamin $z$ Zagłady (ukazał się w językach hebrajskim oraz polskim); opublikowała następujące książki poetyckie: Nie zdążyłam (1998), Tu i tam (1999), Wdychać glęboko (2002), Spóźniona/Delayed (2016). Jej pierwszy zbiór prozatorski pt. Osmaleni (1999) w 2000 roku nominowany był do Nagrody Literackiej Nike, podobnie następny - Podwójny krajobraz (2008); w Polsce wydała jeszcze autobiografię Życie - tytuł tymczasowy (2016).

$\mathrm{Na}$ język hebrajski przekładała utwory Marka Hłaski, Henryka Grynberga, Hanny Krall i innych; jest też tłumaczką poezji hebrajskiej na język polski, m.in. Abrahama Koplowicza, Hanocha Levina, Dana Pagisa.

Marta TomczoK - autorka książek Trofea wyobraźni. O prozie Leo Lipskiego, Metonimie Zagłady. O polskiej prozie lat 1987-2012, Czyja dzisiaj jest Zagłada. Retoryka - ideologia - popkultura, redaktor naczelna rocznika „Narracje o Zagładzie”, kierownik Centrum Studiów nad Dyskursami Zagłady przy Wydziale Humanistycznym Uniwersytetu Śląskiego. Pracuje w Instytucie Literaturoznawstwa na stanowisku adiunkta. Zajmuje się oddziaływaniem Holokaustu na kulturę najnowszą, w tym jego związkami z popkulturą, postmodernizmem i postpostmodernizmem. 